\title{
Interpretacje w naukach społecznych - aspekty teoretyczne i metodologiczne
}

\section{Interpretations in Social Sciences - Theoretical and Methodological}

\section{Aspects}

\begin{abstract}
Presented article offers a general overview of the interpretive approaches in the social and political sciences. The article starts with the definitions and etymology of the term "interpretation" and its synonyms. In the section 1 the author refers to the interpretive methodology of Max Weber and its actuality in the academic disciplines such as ethnography, sociology, history and law. The section 3 explains the usefulness of interpretive methods in doing research within a qualitative methodology in the social and political sciences. Sections 4 and 5 describe the nature of relations between interpretation, understanding and explanation. The last section brings attention on the application of interpretive methodology in the political science and political theory. Instead of a summary the author shares a reflection on the condition of science and a future of interpretative studies.
\end{abstract}

Keywords: interpretation, understanding, explanation, qualitative research, theory of politics

\section{Kwestie definicyjne}

Termin „interpretacja” ma wiele znaczeń. Jego łaciński źródłosłów to interpretatio - „wyjaśnienie”, od interpretari - „wyjaśniać, tłumaczyć” (Kopaliński, 1968, s. 340). W starożytnym Rzymie terminem interpretatio romana nazywano pro- 
ces adaptowania greckich bogów do panteonu bogów rzymskich ${ }^{1}$. Elitarna grupa kleryków, zwanych augures, interpretowała loty ptaków nad Kapitolem, z których odczytywano znaki z niebios. Inna grupa duchownych specjalizowała się w zapożyczonej od Etrusków sztuce interpretowania woli bogów z organów zwierząt ofiarowanych bóstwom podczas licznych ceremonii ku ich czci. Na wzgórzu kapitolińskim, w monumentalnej świątyni trzech najważniejszych rzymskich bogów trzymano pod strażą święte księgi, z których duchowni interpretowali zawarte $\mathrm{w}$ nich przepowiednie i wskazówki, jak uniknąć nieszczęść dla miasta. W literaturze naukowej podejście interpretatywne jest powiązane lub utożsamiane $\mathrm{z}$ hermeneutyką. Termin „hermeneutyka” wywodzi się z języka greckiego (hermeneuticos), gdzie oznacza „dotyczący wyjaśniania” (Kopaliński, 1968, s. 302). W metodologii nauk społecznych hermeneutyka to nauka interpretacji. Jak pisze John Gerring, termin ten używany jest w naukach społecznych w odniesieniu do podejść, które preferują subiektywną interpretację nad ogólnie przyjęte standardy badań naukowych (Gerring, 2007, s. 214). Praźródła hermeneutyki prowadzą do starożytnej techniki egzegezy tekstów religijnych ${ }^{2}$. Greccy filozofowie w późnej starożytności i na początku ery nowożytnej zajmowali się interpretacją snów, czemu towarzyszyła wiara, że sny mają znaczenie dla przyszłości jednostki. Michel Foucault wymienia praktykę interpretowania snów jako jedną $\mathrm{z}$,technik siebie”, uprawianą w starożytnej filozofii greckiej począwszy od stoików i Platona. Podaje przykład Arystydesa, który w księdze Święte mowy interpretował swoje sny. Filozof ów wierzył, że podczas interpretacji snów bogowie zsyłają ludziom wskazówki leczenia chorób (Foucault, 2000, s. 267). Etymologia słownikowa pojęcia ,interpretacja” sięga XIII wieku, kiedy termin ten pojawił się w pierwszych leksykonach języka angielskiego i francuskiego. Przypisywano mu wówczas znaczenia takie jak wyjaśnienie, ekspozycja lub zrozumienie. $\mathrm{W}$ drugiej połowie XIV wieku poszerzono leksykalne znaczenie terminu o akt wyjaśniania lub interpretowania. Współcześnie słownik języka angielskiego hasło „intepretować” (interpret) tłumaczy jako „wyjaśniać, wyrażać artystycznie” (The Cambridge English Dictionary, 1990, s. 217). Interpretacja to akt interpretowania, wyjaśniania, ale także reprezentacja postaci na scenie. Według Słownika języka polskiego interpretacja to: „wyjaśnienie sensu lub znaczenia czegoś, 1. zarządzenia, ustawy, 2 sposób wykonania utworu muzycznego, literackiego lub teatralnego" (Słownik języka polskiego, 2008, s. 279). Z kolei Kopalińskiego Słownik wyrazów obcych i zwrotów obcojęzycznych hasło „interpretacja” tłumaczy jako „wykładnia, wyjaśnienie, wytłumaczenie, komentowanie czegoś, sposób odtworzenia lub wykonania utworu muzycznego, zagrania roli przez aktora" (Kopaliński, 1968, s. 340). Amerykański słownik synonimów i antonimów wy-

Np. odpowiednikiem Zeusa był najważniejszy bóg rzymski Jupiter.

W greckiej mitologii bóg Hermes był wysłannikiem najwyższego boga na Olimpie - Zeusa, który wyróżnił go misją przekazywania i tłumaczenia ludziom jego boskiej woli. 
mienia następujące synonimy rzeczownikowe pojęcia „interpretacja” (interpretation): „definicja, diagnoza, znaczenie, wyjaśnienie, eksplikacja, translacja, konstrukcja, egzegeza”. Dla hasła „interpretować” tenże słownik podaje synonimy: wyjaśnić, zrozumieć, definiować, konstruować, tłumaczyć, odcyfrować, rzucić nowe światło lub świeże światło (Rogets’s Thesaurus..., 1987, s. 104).

Istnienie wielu synonimów sugeruje złożoność podejścia interpretacyjnego. W literaturze metodologicznej brakuje definicji pojęcia „interpretacja”. Być może jest tak dlatego, że jak zauważa Stanisław Filipowicz, interpretacja nie zawsze jest bezpośrednio widoczna, ale „bardzo często jest zakonspirowana, zaszyfrowana jako obserwacja, jako "obiektywne» badanie rzeczy" (Filipowicz, 2015, s. 193). W teorii polityki interpretacja utożsamiana jest z objaśnianiem trudnych do zdefiniowania terminów (Klementewicz, 2010, s. 132-133). W pracach teologicznych interpretacja odnosi się do egzegezy tekstów biblijnych w różnych religiach.

Interpretacja jest kluczowym elementem teorii prawa. Jeden z twórców amerykańskiej konstytucji Alexander Hamilton pisał w 1787 roku, iż „Prawa pozostają martwą literą bez sądów, które definiują ich prawdziwe znaczenie i działanie" (cyt. za: Peck, 1987, s. 145). Interpretacja jako proces wykładni zasad, przepisów i terminów prawnych wykorzystywana była w prawie rzymskim i od tego czasu stanowi nieodłączny element postępowania sądowych organów stosujących prawo. W literaturze prawniczej termin „interpretacja” jest używany zamiennie z pojęciami wykładni przepisów prawnych lub tekstu prawnego. „Wykładnia, czyli inaczej interpretacja prawa, oznacza proces ustalania znaczenia przepisów prawnych albo produkt (wynik) tej czynności" (Chauwin, Stawecki, Winczorek, 2007, s. 235). Interpretacja prawa występuje w sensie largo i stricto. Pierwszy dotyczy sytuacji, kiedy interpretacji poddaje się wszystkie wypowiedzi lub przepisy prawne, drugi - „kiedy powstają wątpliwości co do właściwego znaczenia faktu w jego bezpośrednim rozumieniu". Celem interpretacji jest usunięcie niejasności tekstu prawnego (Zieliński, 2017, s. 58). Interpretacja nie jest potrzebna, jeśli znaczenie tekstu/przepisu jest jasne, klarowne (łac. clara non sunt interpretanda).

Interpretacja jako metoda badań jakościowych stanowi element procesu badawczego mającego na celu wyjaśnianie działań aktorów społecznych na podstawie poznawania ich intencji, celów i wartości, nadających sens działaniom (Klementewicz, 2010, s. 111). Przedmiotem interpretacji są także wytwory działań, takie jak dzieła naukowe, teksty prawne, teksty biblijne, ideologie, dyskursy, powieści, filmy, seriale telewizyjne itp. Interpretacja może oznaczać proces myślowy (intelektualny) podmiotu interpretującego lub jego rezultat - fakt, stan dokonany. $\mathrm{W}$ tym znaczeniu termin jest bliski takim pojęciom jak rekonstrukcja, reprezentacja lub wyjaśnienie/objaśnienie. Zakładamy przy tym, że obiekty poddawane interpretacji (działania i ich wytwory) stają się zrozumiałe (jasne, klarowne) dla adresatów: naukowców, prawników, czytelników, krytyków filmo- 
wych etc. Metody interpretacji w odniesieniu do bezpośrednio obserwowanych działań będą się w istotny sposób różnić od metod interpretacji tekstów filozoficznych, ideologii politycznych, myśli politycznej, wydarzeń historycznych, tekstów prawnych etc. Każdy z tych obiektów wymaga specyficznego podejścia, technik analizy i kompetencji podmiotu interpretującego.

Istotną rolę w teorii interpretacji odgrywa reinterpretacja, czyli nowe rozumienie, wyjaśnienie lub teoria jakiegoś zjawiska bądź grupy zjawisk. Natura realizowanych projektów badawczych skłania często ich uczestników do ponownego przemyślenia danych, pojęć i procedur w świetle uzyskanych rezultatów. Inny bliskoznaczny termin to „rekonstrukcja”, czyli możliwie dokładne odtworzenie wydarzenia, dzieła sztuki, biografii, myśli politycznej etc. Rekonstrukcja faktów i procesów historycznych zawsze zawiera jakiś element autorskich interpretacji, które uzupełniają luki w dostępnym materiale źródłowym poprzez wyobraźnię interpretatora. Efektem może być błędna interpretacja zdarzeń lub roli w nich postaci historycznych. Filmowe rekonstrukcje wielkich bitew czy biografii bohaterów żyjących w odległej przeszłości często mijają się z prawdą historyczną. Lisa Fagin Davis zwraca uwagę na nieprofesjonalne interpretacje historii średniowiecza. Jej zdaniem autorzy często fałszywie lub tendencyjnie interpretują średniowieczne fakty i symbole. Tymczasem „aby prawdziwie zrozumieć przeszłość, musimy jej pozwolić mówić samej za siebie" (Davis, 2019).

\section{Interpretacja w tradycji weberowskiej}

Podejście interpretacyjne $\mathrm{w}$ naukach społecznych czerpie inspirację $\mathrm{z}$ tradycji hermeneutycznej w filozofii i socjologii, której podstawy stworzyli i rozwijali Immanuel Kant, Max Weber, Wilhelm Dilthey, Hans-Georg Gadamer, Anthony Giddens i inni. Wielkie zasługi w historii tego podejścia ma w szczególności Weber, twórca tzw. socjologii rozumiejącej. Weber wielokrotnie posługuje się pojęciem interpretacji, chociaż nie definiuje tego terminu. Interpretacja jest $\mathrm{w}$ jego metodologii metodą rozumienia lub wyjaśnienia hermeneutycznego. Weber rozumiał interpretację jako narzędzie, za pomocą którego „socjologia dąży do zrozumienia sensu działania lub działania społecznego i przez to do przyczynowego wyjaśnienia jego przebiegu i skutków" (Weber, 2002, s. 6). Obok terminu "interpretacja” autor posługuje się terminem „interpretacja intelektualna”. Ta pierwsza ,jak każda nauka dąży do oczywistości”, prowadzi do zrozumienia działań racjonalnych. W stosunku do innych działań, których nie udaje się w pełni zrozumieć, badacz musi się zatem zadowolić „intelektualną interpretacją" (Weber, 2002, s. 7). Uczony uważał, że głównym zadaniem socjologii jest zrozumienie „struktury sensu” (znaczenia) ludzkich działań. Podmiot działa pod wpływem wewnętrznego motywu, który nadaje mu sens. Działanie jest dobrowolne i celowe, odzwierciedla subiektywny sens lub znaczenie dla pod- 
miotu. Tym się różni działanie od zachowania, które ma charakter niedobrowolny, odruchowy, jak bezwolne reakcje organizmu na rozmaite bodźce zewnętrzne. W konceptualizacji Webera „działania” różnią się od „działań społecznych”. Te drugie są ukierunkowane na relacje z innymi ludźmi. Uczony miał świadomość, że realne działania jednostek powodowane są różnymi, często irracjonalnymi i sprzecznymi pobudkami. Docieranie do subiektywnego sensu irracjonalnych struktur uczuciowych (ambicja, strach, traumatyczne przeżycia) nasuwa rozliczne trudności i ograniczenia poznawcze. Poszukując sposobu przezwyciężenia bariery poznawczej, Weber wprowadził pojęcie „idealnej racjonalności”, abstrakcyjny termin (typu idealnego), dzięki któremu możliwe jest porównywanie stanu realnego ze stanem racjonalności istniejącym tylko hipotetycznie. Obserwując i porównując odchylenia realnych działań konkretnych jednostek w stosunku do działania idealnie racjonalnego, możemy lepiej zrozumieć stan poszczególnych przypadków. Tradycja weberowska nie traktuje świata znaczeń i świata naturalnego jako bytów zasadniczo sprzecznych. Nie uważa, że metody interpretacyjne to jedyne metody badania zjawisk znaczeniowych. Weber nie twierdził nic ponad to, że metody te dają sposobność lepszego zrozumienia kompleksowości świata. Kontynuowana przez następne pokolenia uczonych weberowska tradycja hermeneutyczna kładzie większy nacisk na „naukę interpretacji”. Wyżej ceni pojęcie rozumienia niż ogólnie przyjęte standardy metody naukowej w naukach empirycznych. Separuje zadanie rozumienia znaczeń i wewnętrznych impulsów myślącego podmiotu od wyjaśniania zjawisk i procesów zachodzących w świecie naturalnym. W tym względzie zdeklarowani zwolennicy hermeneutyki zapominają o ważnych elementach myśli klasyka. Weber opowiadał się za hermeneutycznym podejściem do wyjaśniania działań aktorów społecznych, uważał jednak, że podejście to jest niewystarczające, aby uzyskać pełne zrozumienie działania. Potrzebny jest pewien zakres obiektywizacji podejścia badawczego, która wskaże zewnętrzne przyczyny skłaniające ludzi do działania (Sadri, 1992, s. 140-141). Tradycję weberowską podtrzymywał w metodologii historii Jerzy Topolski. W nauce o polityce koncepcje wyjaśniania „integralnego" prezentuje i rozwija Tadeusz Klementewicz. W tym ujęciu wyjaśnienie integralne (pełne) działań społecznych i politycznych bierze pod uwagę łącznie element rozumienia i przyczynowości. Pierwsze odwołuje się do intencji podmiotu, drugie - do obiektywnych przyczyn strukturalnych warunkujących działanie (Klementewicz, 2010, s. 110).

\section{Interpretacja jako metoda badań jakościowych}

Przedstawiciele interpretacyjnego nurtu w filozofii nauki podkreślają specyfikę nauk społecznych, których przedmiotem jest człowiek, kultura i społeczeństwo (Benton, Craib, 2003, s. 98). Wielu metodologów przyjmuje tezę o społecznie 
konstruowanej naturze rzeczywistości, zapożyczoną z konstruktywizmu (Moses, Knutsen, 2007, s. 146-149). Ich zdaniem nauki społeczne nie mają na celu poszukiwać uniwersalnych praw, bo takowe w świecie społecznym nie istnieją. Celem nauk o człowieku jest dążenie do zrozumienia sensu ludzkich działań, a nie poszukiwanie (mitycznych) praw rządzących światem społecznym. Specyficzny przedmiot badań wymaga posługiwania się specyficznym podejściem metodologicznym i zbiorem metod. Jego istotą jest analiza danych jakościowych - dokumentów, opowieści, danych z pogłębionych wywiadów itp. Podejście interpretacyjne ma kluczowe znaczenie dla takich dyscyplin jak filozofia, socjologia, historia, prawo i politologia. W ogólnie stosowanym w podręcznikach metodologii nauk społecznych podziale metod badawczych na ilościowe i jakościowe metody interpretacyjne zaliczane są do tych drugich. W metodologii badań jakościowych badacze na ogół nie stosują metod statystycznych ani eksperymentalnych. Pomocne okazują się natomiast badania porównawcze różnych interpretacji zjawisk, tradycji, idei politycznych, doktryn lub ideologii. Celem badaczy jest wyjaśnienie bądź zrozumienie motywów działań aktorów społecznych z perspektywy interpretacji humanistycznej, kierującej uwagę na idealistyczne przesłanki działania (idee, preferencje, wierzenia, przekonania) oraz ich znaczenie dla działającego podmiotu. Jeśli celem badania jest zrozumienie obyczajów lub stylu życia określonej grupy, badacz powinien zadbać o rzetelność i wiarygodność opisu. Pisemna narracja autorska powinna odzwierciedlać stan świadomości społecznej respondentów, reprezentujących kolektywną mentalność badanej społeczności.

Metody badań jakościowych różnią się w zależności od przedmiotu zainteresowań i celów, jakie przyświecają badaczom. W badaniach etnograficznych przeważają metody obserwacji zwykłej i partycypacyjnej, wywiadu pogłębionego, studiowania narracji autobiograficznych. W badaniach myśli politycznej standardowe metody to studiowanie źródeł, takich jak autobiografie, osobiste wspomnienia, dzienniki, listy, dokumenty oficjalne. Źródła wytworzone to bezpośrednie wywiady, konwersacje z autorami, krytykami etc. Szczególnie widoczna jest użyteczność metodologii i metod interpretacyjnych w badaniach etnograficznych (etnologicznych). Celem tych badań jest pogłębienie wiedzy o motywach zachowania jednostek, członków grup na podstawie obserwacji i wywiadów, studiowania biografii, tożsamości, doświadczeń i przeżyć członków różnych grup, takich jak mniejszości etniczne, weterani wojen lub powstań narodowych, uczestnicy ruchów protestu i szczególnych wydarzeń politycznych. Jak pisze Zoe Bray: „Podejście etnograficzne zajmuje centralne miejsce w naukach społecznych i politycznych z powodu jego holistycznego i naturalistycznego charakteru, który ma fundamentalne znaczenie dla głębokiego zrozumienia istoty ludzkiej jako społecznego podmiotu" (Bray, 2008, s. 314). Istotą podejścia etnograficznego jest zgłębianie motywów działań (intencji, pragnień, osobistych doświadczeń) osób zamieszkałych w konkretnym miejscu lub regionie w spe- 
cyficznym kontekście kulturowym. W badaniach etnograficznych interpretacja odgrywa pierwszoplanową rolę, ponieważ celem tych badań jest zrozumienie perspektywy myślenia i działania jednostek w specyficznym kontekście ich codziennego życia (Bray, 2008, s. 305). Kompetentny badacz powinien dążyć do zrównoważenia subiektywizmu i obiektywizmu, wyrażać z jednej strony empatię wobec badanych, a $\mathrm{z}$ drugiej postawę bezstronnego obserwatora, poddając rozważnej interpretacji dane uzyskane za pomocą metod akceptowanych w środowisku naukowym. Dla powodzenia projektu badawczego naukowiec powinien już na wczesnym etapie dokonać autorefleksji w celu zrozumienia i kontrolowania własnej kompetencji interpretacyjnej do pracy z respondentami $\mathrm{z}$ innej kultury, regionu świata, rasy, ideologii, światopoglądu, pozycji społecznej etc. Jak pisze John W. Creswell: „Badanie jakościowe jest badaniem interpretacyjnym. Każdy badacz prezentuje własne rozumienie obserwowanych zjawisk i problemów” (cyt. za: Silbergh, 2001, s. 132). Wyniki badań jakościowych są trudne do zweryfikowania i w większości niemożliwe do powtórzenia na tej samej próbie i w tych samych warunkach przez innych badaczy.

Jak wspominano wcześniej, podejście interpretacyjne uchodzi za kluczowy element badań jakościowych. Istotą badań jakościowych jest zgromadzenie możliwie dużej ilości danych dotyczących przedmiotu obserwacji. W badaniach jakościowych uwaga badacza zazwyczaj skupia się na dokładnej eksploracji małej liczby jednostek analizy lub przypadków dobranych w sposób celowy (teoretyczny bądź celowy dobór próby). Materiał źródłowy zgromadzony przez badacza (stenogramy, nagrania z wywiadów, opowieści, wspomnienia, relacje ustne itp.) poddawany jest przezeń interpretacyjnej analizie. Autorzy projektów opracowują wnioski z badań obserwowanych jednostek lub grup w postaci możliwie wnikliwego i rzetelnego opisu obszernych wypowiedzi (narracji) zasłyszanych od respondentów. Narracje to opowieści jednostek usytuowanych w kontekście społecznym i kulturowym, konkretnym miejscu i czasie. Indywidualne narracje przyczyniają się do zrozumienia wydarzeń o znaczeniu historycznym, opowiedzianych przez ich aktywnych uczestników albo bezpośrednich obserwatorów (świadków historii). Zrozumienie sensu narracji dla ich autorów wymaga wnikliwej analizy interpretacyjnej. Molly Andrews pisze, że zrozumienie sensu indywidualnych opowieści uczestników przełomowych wydarzeń politycznych możliwe jest tylko w ramach określonego kontekstu politycznego i historycznego. Sensu wypowiedzi możemy się doszukać tylko wówczas, kiedy zrozumiemy, jakie znaczenie respondenci przywiązują do wydarzeń, w których uczestniczyli, i w jaki sposób rozumieją swój własny udział w tych wydarzeniach (Andrews, 2007, s. 204-206). Z punktu widzenia badacza jednostkowych narracji ważne jest dokonanie właściwej interpretacji wypowiedzi, zrozumienie zawartego w niej sensu. Autorka wyraża przekonanie, że zinterpretowane w jej monografii opowieści wybranych osób aktywnych w czasach przełomów politycznych (upadek muru berlińskiego, upadek apartheidu w RPA, szok polityczny w USA po 
tragicznych atakach terrorystycznych z 11 września 2001 roku) powinny pomóc w lepszym zrozumieniu czasów, w jakich żyjemy, a także znaleźć głębsze podstawy rozumienia losów jednostek w szerszych ramach społecznych i politycznych, które nadają im znaczenie. „Owa dynamika napięcia między biografią a historią stymuluje bicie serca narracji politycznych" (Andrews, 2007, s. 209). Socjolożka Stella Grotowska wyjaśnia, iż w podejściu interpretatywnym „działanie ludzkie pojmowane jest jako «tekst», zbudowany z symboli mających dla podmiotów określone znaczenie" (Grotowska, 2011, s. 73). Przedmiotem interpretacyjnych badań własnych tej autorki są - jak pisze - „narracje badanych, przekazywanie własnego punktu widzenia, osobistego doznania, subiektywnego obrazu świata" (Grotowska, 2011, s. 81). Na podstawie wywiadów z dobraną celowo grupą seniorów (w większości płci żeńskiej) zaangażowanych w dobroczynną działalność w stowarzyszeniach religijnych działających przy parafiach rzymskokatolickich we Wrocławiu socjolożka poszukuje (i znajduje) klucz do zrozumienia aktywizmu respondentów. W konkluzji pracy identyfikuje dwa główne motywy aktywizacji badanych osób: 1) poczucie działania wspólnego, włączenia w nurt życia społecznego; 2) poczucie robienia czegoś bezsprzecznie wartościowego. W ten sposób badaczka ukazała (odkryła) wymiar transgresyjny aktywizacji społecznej osób starszych, polegający „na wyjściu z domu, przekraczaniu granicy oddzielającej sferę prywatną od publicznej, kreatywności, edukacji całożyciowej i dobroczynności" (Grotowska, 2011, s. 243).

Dotarcie do idealizacyjnych motywów działania aktorów społecznych wymaga od badaczy skutecznego, ale zarazem etycznego posługiwania się metodami jakościowymi, wśród których na pierwszym planie znajdują się umiejętności wytworzenia własnych danych i dotarcia do zastanych danych źródłowych (autobiografii, narracji, opowieści, mitów, konwersacji, praktyk symbolicznych). Do podstawowych metod stosowanych w badaniach zalicza się wywiad bezpośredni (swobodny lub częściowo ustrukturyzowany), obserwację zwykłą, obserwację partycypacyjną, wywiad grupowy, analizę dyskursu, studiowanie autobiografii. Badacz powinien posiadać umiejętność doboru próby respondentów, aktywnego słuchania podczas prowadzenia wywiadu, empatycznego podejścia do osób badanych w kontekście opowieści ich życia i osobistych doświadczeń. W końcowej fazie projektu pojawia się zadanie przemyślenia i zinterpretowania uzyskanych informacji oraz autorskiej refleksji nad przebiegiem badania, oceny adekwatności wyników do zamierzeń badawczych. Od badacza oczekuje się zrozumienia własnej tożsamości kulturowej, światopoglądowej, stosunku do innych kultur i religii, stereotypów i uprzedzeń. Interpretacja danych autobiograficznych jest w znacznym stopniu subiektywną interpretacją autorską, ale nie powinna być nadmiernie spersonalizowana. Narracja ma spełniać jakościowe kryteria dające podstawy do jej oceny w środowiska akademickim. Różne interpretacje tego samego zjawiska lub obiektu powinny podlegać profesjonalnej ocenie innych badaczy, recenzentów, uczestników konferencji i seminariów pod 
względem stopnia ich wiarygodności, rzetelności i weryfikowalności. Podniesienie poziomu wiarygodności osiąga się przez dokładność w opisie procedury badawczej, ujawnienie źródeł, cytowanie obszernych fragmentów wypowiedzi respondentów. Ten ostatni zabieg zwiększa autentyczność i reprezentatywność interpretacji. Badacze powinni zadbać o wyraźne sformułowanie celów, pytań badawczych i procedur gromadzenia danych (faktów). Historycy myśli politycznej zwracają uwagę na przestrzeganie zasad rygoryzmu metodologicznego, do którego zalicza się „określenie celu badań, planowanie i kierowanie badaniem, gromadzenie wiedzy źródłowej, przetwarzanie, analiza, opracowanie, upowszechnianie efektów dociekań naukowych" (Maj, 2018, s. 65). Na drodze do obiektywizmu badacze myśli politycznej natrafiają na różne ograniczenia poznawcze. Ewa Maj zalicza do nich „słabą znajomość konstruowania opowieści, tworzenia fabuły, posługiwania się narracją jako instrumentem poznawczym, wykorzystania technik narracyjnych do wchodzenia w interakcję z kulturą, pamięcią i osobowością" (Maj, 2018, s. 71). Trzeba jednak mieć świadomość, że żadna interpretacja zjawisk społecznych nie może sobie rościć prawa do idealnej rekonstrukcji opisywanych zjawisk. Bent Flyvbjerg zauważa, iż nie wszystkie interpretacje mogą być uznane za równorzędne. Różnią się one pod względem ważności, stopnia staranności odczytania przez autora uzyskanych danych, jak też stopnia relewancji danych do zdefiniowanego problemu badawczego (Flyvbjerg, 2001, s. 131). Jak pisze Roxanne L. Euben, lepsze narracje interpretacyjne to takie, „w których badane osoby mogą rozpoznać siebie, własne znaczenia przypisywane swoim działaniom, i nawet zgodzić się z nimi” (cyt. za: Moses, Knutsen, 2007, s. 200). Andrews zauważa, że każdy projekt badawczy portretuje uczucia, poglądy i sposoby rozumienia respondentów tylko w określonym dniu, momencie ich życia, umożliwia tylko częściowy wgląd w ich życie (Andrews, 2007, s. 205). Mark Bevir i R.A.W. Rhodes jako kryteria rozpoznania poziomu obiektywności interpretacji proponują „dokładność, wyczerpujący charakter, spójność i otwieranie możliwości nowych badań”. Zdaniem autorów obiektywność wyłania się z krytyki porównywania konkurencyjnych sieci interpretacyjnych dotyczących ustalonych faktów. Przyznają, że najlepsza interpretacja nie oznacza takiej, „której zgodność z prawdą nie budziłaby wątpliwości”. Jako przykład zastosowania metody porównawczej autorzy przeprowadzili analizę sposobu interpretowania ideologii thatcheryzmu przez główne nurty brytyjskiej myśli politycznej: konserwatywny, liberalny, wigowski i socjalistyczny. W konkluzji skonstatowali, że każda z tradycji przedstawia inny obraz zjawiska, jakim był thatcheryzm, „żadna nie jest bezspornie trafna ani bezspornie błędna” (Bevir, Rhodes, 2006, s. 42 i 148).

Występowanie różnych interpretacji tych samych zjawisk rodzi problem obiektywności/neutralności i subiektywizmu/relatywizmu wiedzy produkowanej przez dyscypliny, dla których interpretacja jest jedną z najważniejszych metod. W dyskursie naukowym współistnieją różne interpretacje tych samych 
zjawisk (faktów historycznych, zdarzeń, biografii, mitów, dzieł artystycznych), które uchodzą za równorzędne pod względem poprawności argumentacji, ale nawiązują do różnych tradycji intelektualnych lub politycznych. Różne interpretacje mogą się wykluczać bądź uzupełniać. Nowa interpretacja (zdarzenia historycznego, tekstu, mitu) może zrewidować albo częściowo zmienić interpretację dotychczas uważaną za wiodącą w danej dziedzinie wiedzy. Im bardziej złożony i oddalony w przeszłości jest obiekt lub zjawisko, tym więcej pojawia się interpretacji na jego temat. Bez pomocy znawców dzieł sztuki, takich jak średniowieczne księgi biblijne czy portrety władców, dzisiejsi odbiorcy często nie potrafiliby zrozumieć zawartych w nich metafor i symboli.

Interpretacja stanowi nieodzowny element procesu badawczego niemal w każdej dyscyplinie nauki. Dotyczy to zwłaszcza dyscyplin nauk społecznych i humanistycznych, takich jak filozofia, historia, w tym historia sztuki, socjologia, prawoznawstwo oraz po części nauka o polityce. Podejście interpretacyjne zdobyło szczególne uznanie w tych nurtach filozofii i nauki (hermeneutyka, konstruktywizm, postmodernizm), które krytycznie odnoszą się do pozytywizmu i empiryzmu w badaniach naukowych. Stanisław Filipowicz postrzega rolę interpretacji jako przeciwwagę dla dominującego wpływu w metodologii tradycji pozytywistycznej z jej „fetyszem” metody naukowej. Jego zdaniem nieuchronność interpretacji „wynika z faktu, że sfera poznania i komunikowania nie może istnieć bez pośrednictwa języka" (Filipowicz, 2015, s. 193). Dotyczy to także badań empirycznych, chociaż nie w takim stopniu jak teoretycznych. $\mathrm{W}$ naukach humanistycznych i prawnych interpretacja jest niezbędna $\mathrm{z}$ uwagi na wieloznaczność i nieokreśloność pojęć, jakimi posługują się te dyscypliny. John G. Gunnell twierdzi, że „fundamentalny problem nauk społecznych polega na znalezieniu języka reprezentacji, który zdoła adekwatnie odzwierciedlić i objaśnić (clarify) znaczenie faktów społecznych, a jednoczenie uniknąć reifikacji lub pomieszania formy językowej z reprezentowanym zjawiskiem" (Gunnell, 2017, s. 195). Jest to problem dobrze znany w metodologii od czasu, kiedy Ludwig Wittgenstein ogłosił tezę, iż słowa nie mają absolutnego, raz na zawsze przypisanego znaczenia. Żadne definicje nie są w stanie w pełni doprecyzować znaczenia terminów, jakimi posługują się nauka i filozofia. Co więcej, znaczenia słów zmieniają się wraz z czasem i kontekstem, w jakim są używane.

Socjolodzy prowadzący badania terenowe nieustannie interpretują informacje pozyskane metodą obserwacji i wywiadów, poszukując sposobów zrozumienia obyczajów i stylów życia badanych jednostek oraz grup w zmieniającym się kontekście społecznym i historycznym. Wybitny socjolog amerykański Charles Wright Mills (1959) pod adresem czytelników swoich prac skierował następującą wskazówkę: „Nieustannie twórzcie i rewidujcie swoje poglądy na problemy historii, problemy biografii, problemy struktury społecznej, w której przecinają się biografie i historia. Miejcie oczy otwarte na różnorodność indywidualności życiowych i trendy epokowych zmian" (cyt. za: Andrews, 2007, s. 209). 
Historycy opierają swoje badania na interpretacjach dostępnych źródeł. Historia państw i narodów podlega wciąż nowym (re)interpretacjom. Niektóre wersje różnych wydarzeń i roli w nich narodowych bohaterów powstają na zamówienie tzw. polityki historycznej, narzucanej opinii publicznej przez rządzące w danym czasie elity polityczne. Sprawia to, że interpretacja jako metoda badań historycznych traci na prestiżu. Inaczej należy oceniać prace historyków, którzy nie ulegając ideologicznej presji, kierując się przesłankami naukowymi, oferują nowe interpretacje na podstawie nowych podejść teoretycznych. Przykładem może być praca historyka średniowiecza Caspara Hirschiego, który wprowadza nową interpretację nacjonalizmu i odnajduje wczesne ślady myśli narodowej w dyskursach humanistów europejskich w XV i XVI wieku (Hirschi, 2012, s. 9).

Bez metody interpretacyjnej trudno byłoby się obejść $\mathrm{w}$ badaniach kulturoznawczych. Kultura jest systemem idei, wartości i znaczeń, „idealną substancją”, która „istnieje wyłącznie w ludzkich umysłach” (Scott, 2011, s. 19). Należą do niej idee, przekonania, tradycje, symbole etc. Kultura ma wymiar indywidualny i kolektywny, a wymiary te są wzajemnie współzależne. Nowe idee powstające w umysłach jednostek kreują zmiany w mentalności społecznej i politycznej. W każdym społeczeństwie jego członkowie funkcjonują w ramach ograniczeń i presji kulturowych. Aby zrozumieć sens działań aktorów społecznych i politycznych, niezbędne jest poznanie i zrozumienie kulturowych uwarunkowań ich życia.

\section{Interpretacja a rozumienie}

W literaturze naukowej trudno znaleźć formalną definicję słowa „rozumienie”, mimo że termin jest powszechnie używany w kontekście teorii języka, kultury i komunikacji między ludźmi. Rozumienie może dotyczyć języka, faktów, działań, problemów etc. Może oznaczać aktualny proces kognitywny lub stan dokonany (zrozumienie), który powstaje w umysłach ludzi w toku nabywania i pogłębiania wiedzy. Rozumienie może być pełne lub częściowe. Zdolność rozumienia abstrakcyjnych terminów i teorii przez różnych ludzi jest warunkowane ich inteligencją, wykształceniem, poziomem wiedzy w danej dyscyplinie. Początkiem zrozumienia jest nazwanie obserwowanej rzeczy bądź zjawiska. Przyciągające uwagę zjawisko, które dotychczas nie doczekało się zdefiniowania, stanowi wyzwanie dla nauki (tzw. luka semantyczna). O pełnym zrozumieniu możemy mówić wówczas, kiedy kończy się lista pytań dotyczących danego zjawiska lub problemu (nie oznacza to jednak, że w przyszłości nie mogą się pojawić nowe pytania). Podstawą wzajemnego zrozumienia w środowisku uczonych jest wspólny język - terminy (pojęcia) specyficzne w poszczególnych dyscyplinach naukowych. Abstrakcyjny charakter i wielość znaczeń, jakie różni autorzy przypisują pojęciom, oraz ich zmienność w czasie utrudniają pracę badaczy realizu- 
jących interdyscyplinarne projekty. Droga do rozumienia prowadzi przez wyjaśnienie. Zjawisko czy wyjaśniony fakt stają się zrozumiałe (przejrzyste, jasne) dla adresata (studenta, czytelnika, widza). Max Weber wyróżniał dwa rodzaje rozumienia: bezpośrednie i wyjaśniające (Weber, 2002, s. 8). Rozumienie oznacza dla niego „interpretujące ujęcie intencjonalnego sensu lub struktury sensu” (Weber, 2002, s. 9). Nie wszystkie działania można zrozumieć, odwołując się do ich subiektywnego sensu intencjonalnego. Aby zrozumieć sens działania w ujęciu konkretnym, należy poświęcić uwagę każdej jednostce z osobna, zrozumieć ukryte w umyśle złożone motywy kierujące jej działaniem. Erik H. Erikson wyróżnia trzy wymiary rozumienia: faktualność, realność i aktualność. Pierwszy (factuality) oznacza traktowanie rzeczywistości jako zbioru faktów, których odkrywanie jest celem nauki. Jest to podeście uproszczone, zrozumienie nigdy bowiem nie jest czysto faktualne. Rzeczywistość (reality) to coś więcej niż (zawsze ograniczona) suma zgromadzonych faktów. Fakty same w sobie nie mają samoistnego znaczenia, ich walor poznawczy zależy od metod ich uzyskania, ramy odniesienia, w jakiej nabierają znaczenia, perspektywy, z której je interpretujemy i staramy się zrozumieć zgromadzone fakty. Trzeci wymiar rozumienia (actuality) oznacza jego pogłębienie poprzez włączenie się samego badacza w sferę badanej materii. Przez nabywanie własnego doświadczenia badacz zwiększa swoje zdolności do pełniejszego zrozumienia interesujących go działań, zjawisk i problemów (cyt. za: Hoover, Donovan, 2010, s. 19).

Naukowcy podejmujący badania empiryczne $\mathrm{w}$ tradycji interpretatywnej czynią to z przekonaniem, że stosowane przez nich metody, takie jak obserwacja partycypacyjna, studiowanie biografii i narracji, wywiady w środowiskach respondentów (badania terenowe), pozwolą im „zgłębić rolę jednostki jako aktora społecznego" i na podstawie celowo dobranych jednostek analizy (przypadków) zrozumieć obyczaje i style życia badanych społeczności. Celem badań jest zrozumienie praktyk społecznych badanych jednostek lub grup w codziennym kontekście ich funkcjonowania, sformułowanie odpowiedzi na pytanie, jakie znaczenie przypisują swoim zachowaniom (zwyczajom, tradycjom), jakie wartości pragną zrealizować przez własne zaangażowanie w życie wspólnoty. Mając ambicje naukowe, badacze nie ukrywają empatii do badanych społeczności, stale towarzyszy im świadomość różnorodności ras, grup etnicznych i kultur. Żeby ocenić status naukowy badań interpretacyjnych, trzeba odpowiedzieć na pytanie o wiarygodność interpretacji jako metody badań naukowych. Istotnym składnikiem oceny jest kompetencja interpretacyjna uczestników projektu badawczego, którego elementem są metody interpretacyjne. Pojęcie to powinno obejmować wysoki poziom umiejętności warsztatowych i znajomości norm etyki badań społecznych. Zalicza się do nich zdolność budowania zaufania, wzajemnego zrozumienia i respektu dla badanych osób. Badacz powinien wykazywać w stosunku do badanych pozytywną bezstronność, autentyczność i empatię. Empatia oznacza zdolność zrozumienia przekonań i postępowania innych osób 
z perspektywy ich doświadczeń, przeżyć, wartości i okoliczności zewnętrznych, które wpłynęły na ich wybory życiowe. Zewnętrzna ocena rzetelności i wiarygodności końcowego rezultatu procedury badawczej (artykułu, raportu, monografii) zależy w dużym stopniu od kompetencji interpretacyjnej autora. Interpretacja tekstu biblijnego wymaga rozumienia wierzeń, praktyk i ich rozwoju w czasie, ich kształtowania w przeszłości i współcześnie przez konteksty polityczne, społeczne i kulturowe. Nie można też zapominać o ważnym czynniku, jakim jest autorytet naukowca $\mathrm{w}$ danej dziedzinie wiedzy, jego doświadczenie, wcześniejsze projekty i publikacje. Przed przystąpieniem do badań terenowych w odległych kulturowo kontekstach i tradycjach badacz powinien poddać refleksji własne kompetencje badawcze i kulturowe, powinien być świadomy, że pomimo najlepszych intencji kierowania się obiektywizmem proces interpretacji może być obciążony wpływem różnego rodzaju uprzedzeń: rasowych, religijnych, ideologicznych. Jak pisze Molly Andrews, doświadczona badaczka opowieści aktywnych świadków przełomowych wydarzeń politycznych: „Musimy się uczyć, jak podchodzić do historii, które mogą wykraczać poza naszą wrażliwość kulturową. Oznacza to, że musimy być gotowi, aby dopuścić do siebie prawdy i normy kulturowe odległe lub nawet przeciwne do tych, w jakich zostaliśmy zsocjalizowani" (Andrews, 2007, s. 36). Na zjawisko mitologizowania faktów w badaniach historycznych krytycznie patrzy prof. Howard Zinn, autor poczytnej historii Stanów Zjednoczonych. Jego zdaniem nie ma czegoś takiego jak czysty fakt pozbawiony interpretacji: „Za każdym faktem prezentowanym światu przez nauczyciela, pisarza lub kogoś innego stoi osąd, dzięki któremu ten fakt, a nie inne, został uczyniony ważnym" (Zinn, 1999, s. 684).

\section{Wyjaśnianie interpretacyjne}

Problem wyjaśniania $\mathrm{w}$ naukach społecznych jest od dawna przedmiotem dyskusji w literaturze metodologicznej. Nauki społeczne, wśród nich politologia, dysponują dość szerokim repertuarem metod wyjaśniania zjawisk społecznych. Pośród nich można wymienić wyjaśnienia przyczynowe, statystyczne, funkcjonalne, strukturalne, instytucjonalne, racjonalne, psychologiczne, idealistyczne (Klementewicz, 2010, s. 111). Niektóre z nich znajdują zastosowanie w metodologii ilościowej, ale większość jest narzędziem badań jakościowych. W dorobku nauk politycznych trudno dopatrywać się praw naukowych i teorii pozwalających przewidywać ludzkie zachowania, jak też przyszłe „zachowania" systemów politycznych. Większość istniejących zależności cechuje co najwyżej średni poziom współzależności między różnymi czynnikami. Politolodzy dowiedli istnienia wielu pozytywnych związków między zmiennymi takimi jak poziom edukacji a partycypacja polityczna, kapitał społeczny a poziom za- 
ufania do instytucji politycznych. Wskazują one na istnienie korelacji statystycznych, ale najczęściej nie są to zależności przyczynowe, przeważnie mają charakter probabilistyczny (Jabłoński, 2017, s. 53). Wyjaśnianie interpretacyjne opiera się na założeniach idealistycznych (Parsons, 2007, s. 102). Odwołuje się do idei, przekonań, motywów działania, czyli wyjaśniania wewnętrznego (endogennego) w przeciwieństwie do wyjaśniania zewnętrznego (egzogennego) (Ferejohn, 2004, s. 150). W tym drugim wypadku przyczyn działania poszukuje się w czynnikach niezależnych od badanego podmiotu. Wyjaśnienie interpretacyjne działania aktora (x) w sytuacji (y) polega na wykazaniu przez badacza, że obserwowany podmiot podjął określone działanie (wyłącznie) na podstawie własnych intencji wynikających z jego idei, przekonań lub preferencji. Zmienną wyjaśniającą (niezależną) $(\mathrm{z})$ powinny być idee, przekonania i preferencje badanego podmiotu. Jeśli w analizie uwzględnić, że podmiot (aktor indywidualny lub kolektywny) działa pod wpływem własnej interpretacji swoich idei i przekonań, to mamy do czynienia z tzw. podwójną interpretacją. Rola badacza/interpretatora polega na wtórnej interpretacji (odtworzeniu, rekonstrukcji) stanu świadomości (idei i przekonań) podmiotu w czasie, kiedy podejmował on określone działania (decyzje). Wyjaśnienie interpretacyjne kieruje uwagę na konstelacje czynników ideowych skłaniających ludzi do działania - praktyk, symboli, norm, modeli, przekonań i tożsamości, za pośrednictwem których konkretni ludzie interpretują swój świat. Badanie powinno wykazać, że działania odzwierciedlają własne interpretacje badanych, nie zaś są wynikiem czynników bezpośredniej, obiektywnej pozycji podmiotu (w strukturze społecznej, instytucjonalnej lub psychologicznej). Powinno też wykazać, że działania odzwierciedlają ideowe cechy podmiotu, że podmiot posiadał te cechy, zanim przystąpił do działania, a nie nabył ich $\mathrm{w}$ procesie interakcji $\mathrm{z}$ innymi aktorami. Kulturowy obraz społeczności tworzącej kontekst działania należących do niej jednostek jest zawsze kompleksowy i trudny do zdiagnozowania. Wymaga też precyzyjnej logiki argumentacji. Rezultaty wyjaśnienia interpretacyjnego mogą być dość łatwo podane w wątpliwość przez innych badaczy. Nie spełnia ono standardowej definicji wyjaśnienia naukowego, w myśl której wyjaśnienie to korelacja przyczynowa, która łączy przyczynę i skutek określonego zdarzenia w sposób deterministyczny i powtarzalny (ta sama przyczyna powoduje wystąpienie tego samego zdarzenia w tych samych warunkach) oraz ukazuje mechanizm przyczynowości: czynnik A powoduje stan $\mathrm{b}$ - który powoduje stan $\mathrm{c}$ - który powoduje zdarzenie $\mathrm{B}$ (Van Evera, 1997, s. 14). Wyjaśnienie interpretacyjne często oparte jest na idealistycznej przesłance o racjonalności działania każdego zdrowego na umyśle podmiotu. Jednak w świetle ogólnodostępnej wiedzy uzasadnione wątpliwości budzi zdolność człowieka do racjonalizacji indywidualnych działań z punktu widzenia jasności intencji i celów. Wątpliwość ta dotyczy również, a może nawet bardziej, aktorów politycznych. Ich działania częściej można zrozumieć przez skupienie uwagi na czynnikach innych niż obiektywnie rozumiana racjonalność. Wyjaś- 
nienie interpretacyjne jest bliskie wyjaśnieniu specyficznemu, ograniczonemu do analizy nielicznych przypadków. Ten rodzaj wyjaśnienia nie aspiruje do generalizacji (Gerring, 2009, s. 187-191). Polega ono raczej na wyjaśnieniu konkretnego zdarzenia (faktu), mając na uwadze specyficzny kontekst kulturowy i historyczny, w jakim owo wydarzenie (fakt) miał miejsce.

\section{Podejście interpretacyjne w nauce o polityce}

W metodologii nauk o polityce interpretacja traktowana jest jako ważne podejście badawcze. Głównym polem badań empirycznej politologii jest polityka, której treść nadają działania aktorów (realne, wirtualne, symboliczne). Brytyjscy politolodzy Mark Bevir i R.A.W. Rhodes twierdzą, że do zdefiniowania podejścia interpretacyjnego potrzebne są dwie przesłanki: 1) działania jednostek wynikają z ich przekonań i preferencji; 2) przekonania i preferencje polityczne nie są powodowane oddziaływaniem obiektywnych faktów, zewnętrznych wobec jednostki, takich jak klasa społeczna, rasa czy pozycja, jaką dany podmiot zajmuje w ramach instytucji (Bevir, Rhodes, 2006, s. 134). Zakładają oni, że aktorzy polityczni są w znacznym stopniu autonomiczni, wykazują daleko idącą podmiotowość, mają zdolność do twórczego oddziaływania na otoczenie strukturalne oraz instytucjonalne. W badaniach polityki celem interpretacyjnej procedury badawczej jest wyjaśnianie lub rozumienie faktów, pojęć, dyskursów, narracji etc. odnoszących się do sfery polityki i polityczności. Socjolodzy nauki dowodzą, że wiedza naukowa nie powstaje z próżni, ale jest uwarunkowana społecznie i kulturowo. Fakty są „produktem stylu myślenia”, bywają różnie interpretowane przez różne szkoły naukowe, odkrywanie nowych faktów wymaga zmian w sposobie myślenia. Wyjaśnianie hermeneutyczne polega na interpretowaniu działań z perspektywy ich znaczenia dla aktorów politycznych. Wywiązanie się z tego zadania wymaga wnikliwej obserwacji, gromadzenia wiedzy, logicznego wnioskowania, krytycznego myślenia, ale także intuicji i wyobraźni. Jak wskazują Kenneth Hoover i Todd Donovan (Hoover, Donovan, 2011, s. 5): „Rozsądny osąd jest podstawą ludzkiego rozumienia”. Logika i racjonalny osąd są niezbędne do interpretowania faktów. Termin „osąd” (judgment) oznacza „proces podejmowanie decyzji, w którym aktywują się wszystkie siły umysłu, aby uczynić najlepszy użytek z dostępnej wiedzy" (Hoover, Donovan, 2011, s. 5). Donatella Della Porta i Michael Keating wyróżniają podejście interpretacyjne jako jedno z czterech paradygmatów w naukach społecznych (obok pozytywizmu, postpozytywizmu i humanizmu). W płaszczyźnie epistemologicznej podejście interpretacyjne usytuowane jest między postpozytywizmem a humanizmem. Ten ostatni cechuje najbardziej subiektywna percepcja rzeczywistości społecznej i politycznej (Della Porta, Keating, 2008, s. 22). 
O nieuchronności podejścia interpretacyjnego w nauce o polityce przekonani są liczni przedstawiciele tej dyscypliny, w szczególności teoretycy polityki i badacze myśli politycznej. Badanie intencji aktorów politycznych, znaczeń, jakie ma dla nich zaangażowanie w sferę polityki, wymaga prowadzenia badań interpretacyjnych. Stanisław Filipowicz wskazuje na fundamentalną rolę, jaką interpretacja odgrywa $\mathrm{w}$ politologii. Interpretacja jego zdaniem nie jest tylko jednym z nurtów tej dyscypliny, ale politologia sama w sobie jest nauką interpretującą (Filipowicz, 2015, s. 193). Zbigniew Blok twierdzi, że politologia jako dyscyplina uwikłana $\mathrm{w}$ sferę wartości powinna się orientować $\mathrm{w}$ kierunku interpretacji i rozumienia (Blok, 2017, s. 37). Według Lesliego Paula Thiele'a teoria polityki jest $\mathrm{z}$ natury interpretacyjna. Zadaniem teorii polityki jest „,rozumienie życia politycznego w drodze autorefleksyjnych studiów (...), zrozumienie przez odkrywanie znaczeń, jak ludzie rozumieją siebie i swój świat" (Thiele, 2003, s. 13).

Polityka jest $\mathrm{z}$ natury konfliktowa, co utrudnia obiektywne podejście badacza do jej treści i metod (Jabłoński, 2017, s. 21). Nauka o polityce po części wchodzi w zakres nauk społecznych, a po części zalicza się do dyscyplin humanistycznych. Metody badań politologicznych są zróżnicowane: w zależności od celu i przedmiotu rozważań politolodzy korzystają zarówno z metod ilościowych, jak i jakościowych. Te drugie w dużym stopniu implikują podejście interpretacyjne. Aparat pojęciowy nauki o polityce zawiera liczne terminy ogólne, niedookreślone, wieloznaczne, wielowymiarowe. Zanim zostaną użyte w badaniach empirycznych, wymagają interpretacji w celu ustalenia przez badacza ich znaczenia $w$ kontekście projektu badawczego. Często jest to zadanie bardzo trudne i nie przynosi rezultatu. Symptomem tego faktu jest, że w akademickiej teorii polityki w Polsce od ćwierćwiecza toczą się ożywione spory naukowe wokół definiowania „polityczności” i różnych aspektów tego centralnego dla dyscypliny pojęcia (Czajowski, 2012, s. 73-74; Chmielewski, 2009, s. 33). Politolodzy posługują się interpretacją jako jednym $\mathrm{z}$ wielu podejść badawczych. Metoda interpretacyjna jest przydatna w pewnych obszarach zainteresowań, takich jak kultura polityczna, historia idei politycznych, przywództwo polityczne, instytucje, dyskursy polityczne. Politolodzy starają się zrozumieć motywy działania aktorów politycznych w różnych kontekstach kulturowych, instytucjonalnych, strukturalnych. Odwołują się przy tym do metod jakościowych, takich jak pogłębione wywiady środowiskowe, analiza narracji politycznych, obserwacje bezpośrednie. W europejskiej kulturze metodologicznej większość badań politologicznych opiera się na założeniach i metodach analizy jakościowej. Badania jakościowe cieszą się dużą popularnością zwłaszcza wśród młodych adeptów dyscypliny - magistrantów i doktorantów. Niektórzy krytycy dostrzegają w tym symptom niedorozwoju europejskiej ( $w$ tym polskiej) politologii w porównaniu z amerykańską. Inni wskazują na doniosłą rolę jakościowej metodologii w badaniach nad polityką. David M. Silbergh jest zdania, że wybór metodologii jakoś- 
ciowej motywuje badacza do „szukania sensu problemu politycznego w drodze spersonalizowanej akademickiej interpretacji” (Silbergh, 2001, s. 23-24). Autor polemizuje z poglądem, że badania jakościowe z powodu subiektywizmu są mało ważne dla rozwoju nauki o polityce. Twierdzi, że przy użyciu technik interpretacyjnych badania w tym ujęciu pozwalają na pogłębianie wiedzy o wybranym problemie, a nie tylko szerokie zrozumienie.

Status metodologiczny teorii polityki jest zbliżony do filozofii politycznej. W języku starożytnej filozofii greckiej zadaniem teoretyka było zrozumienie dziejących się wokół wydarzeń. Jan P. Hudzik tłumaczy greckie słowo theoria jako „kontemplacja, spekulacja, oglądanie czegoś”. Teoretyzować (theorein) oznacza „rozważać, spekulować, oglądać” (Hudzik, 2011, s. 53). Teoretyk (theoros) był inteligentnym obserwatorem i interpretatorem wydarzeń/spektakli (thea) dziejących się wokół niego, zadającym sobie pytania i starającym się zrozumieć ich sens. Teoretyzowanie rozumiane było jako forma aktywności intelektualnej, nastawionej na coraz lepsze zrozumienie świata natury i świata społecznego. Współcześnie natura akademickiej teorii polityki oscyluje między teorią empiryczną, normatywną i krytyczną (Blok, 2017, s. 26-29). Teoretycy polityki nie roszczą sobie praw do naśladowania założeń metodologicznych nauk ścisłych, odkrywania przyczynowych praw naukowych, tworzenia korelacji statystycznych i przewidywania przyszłych zdarzeń. Tradycyjnie rozumiana teoria polityki posługuje się metodami interpretacji, narracji tekstowej, krytycznej argumentacji, analizy semantycznej i normatywnej. Jej celem jest analityczny opis, krytyczna reprezentacja, ciągła reinterpretacja idei politycznych, wyjaśnienie interpretacyjne. Teoria polityki poszukuje zrozumienia życia politycznego z puntu widzenia refleksyjnych jednostek - aktorów sceny politycznej.

\section{Zakończenie - antynomie nauki}

Wiedza naukowa jest oparta na celowej i systematycznej obserwacji zjawisk zachodzących w przyrodzie i społeczeństwie, wymagających odkrycia, opisu i wyjaśnienia. Jest produkowana przez naukowców, odwołuje się do obiektywizmu, a nie subiektywizmu. W popularnym rozumieniu „wiedza naukowa to forma wiedzy, która produkuje fakty i twierdzenia oparte na faktach" (Erickson, 2016, s. 72). Badania naukowe poszerzają wiedzę o rzeczywistości, która nas otacza. Wiedza naukowa jest kumulatywna, gromadzona jest przez wiele pokoleń uczonych i badaczy. Nauka wywiera rosnący wpływ na wszystkie dziedziny ludzkiego życia. Doktryna scjentyzmu utrzymuje, że wiedza naukowa stoi wyżej w hierarchii niż inne rodzaje wiedzy, że dzięki nauce można rozwiązać wszystkie problemy, jakie stoją przed ludźmi, nie tylko techniczne lub medyczne, ale także społeczne i polityczne. $Z$ drugiej strony sceptycy w środowisku akademickim i poza 
nim wskazują, że wiedza naukowa jest niepewna i tymczasowa, a teorie naukowe są rewidowane przez nowe odkrycia i ich interpretacje. Ponadto, pomimo niebywałej popularności nauki, w zachodnim świecie mnożą się różnego rodzaju teorie spiskowe (o płaskości Ziemi, o szkodliwości szczepienia dzieci i wiele innych). Niektórzy wpływowi politycy podsycają atmosferę niedowierzania wynikom badań naukowych, kiedy rezultaty badań są dla nich niewygodne. Tworzy to wyzwanie i jednocześnie nowe możliwości dla poważnej naukowej refleksji interpretacyjnej w naukach społecznych.

\section{Literatura}

Andrews, M. (2007). Shaping History: Narratives of Political Change. Cambridge: Cambridge University Press.

Benton, T., Craib, I. (2003). Filozofia nauk społecznych. Od pozytywizmu do postmodernizmu, przeł. L. Rasiński. Wrocław: Wydawnictwo Dolnośląskiej Szkoły Wyższej.

Bevir, M., Rhodes R.A.W. (2006). Teoria interpretacjonistyczna. W: D. Marsh, G. Stoker (red.). Teorie i metody w naukach politycznych, przeł. J. Tegnerowicz. Kraków: Wydawnictwo Uniwersytetu Jagiellońskiego.

Blok, Z. (2017). „Dylematy politologów związane z wyborem opcji metodologicznych”. W: A. Czajowski, L. Sobkowiak, M. Wichłacz (red.). Zjawiska polityczne w perspektywie teoretycznej. Ksiega jubileuszowa dedykowana profesorowi Andrzejowi W. Jabłońskiemu. Wrocław: Wydawnictwo Instytut Politologii UWr.

Bray, Z. (2008). „Ethnographic Approaches”. W: D. Della Porta, M. Keating (ed.). Approaches and Methodologies in the Social Sciences: A Pluralist Perspective. Cambridge: Cambridge University Press.

Chauwin, T., Stawecki, T., Winczorek, P. (2007). Wstęp do prawoznawstwa. Warszawa: Wydawnictwo C.H. Beck.

Chmielewski, A. (2009). „Polityka a etyka Alasdaira MacIntyre’a”. W: A. MacIntyre. Etyka i polityka, przeł. A. Chmielewski. Warszawa: Wydawnictwo Naukowe PWN.

Czajowski, A. (2012). „Polityczność działań społecznych”. W: A. Czajowski, L. Sobkowiak (red.). Polityka i polityczność. Problemy teoretyczne i metodologiczne. Wrocław: Wydawnictwo Atla 2.

Davis, F.L. (2019). „Why Do People Keep Convincing Themselves They've Solved This Medieval Mystery?". The Washington Post, 14.08.2019.

Della Porta, D., Keating, M. (2008). Introduction. W: D. Della Porta, M. Keating (eds.). Approaches and Methodologies in the Social Sciences. Cambridge: Cambridge University Press.

Erickson, M. (2016). Science Culture and Society: Understanding Science in the $21^{\text {st }}$ Century. Cambridge: Polity Press.

Ferejohn, J. (2004). „External and Internal Explanation”. W: I. Shapiro, R.S. Smith, T. Masoud (eds.). Problems and Methods in the Study of Politics. Cambridge: Cambridge University Press.

Filipowicz, S. (2015). „O fundamentalnej roli interpretacji”. Politeja, 36. 
Flyvbjerg, B. (2001). Making Social Science Matter: Why Social Inquiry Fails and How It Can Succeed Again. Cambridge: Cambridge University Press.

Foucault, M. (2000). Filozofia, historia, polityka, przeł. D. Leszczyński. Warszawa-Wrocław: Wydawnictwo Naukowe PWN.

Gerring, J. (2007). Case Study Research: Principles and Practices. Cambridge: Cambridge University Press.

Grotowska, S. (2011). Seniorzy w przestrzeni publicznej. Kapitał społeczny uczestników wspólnot, ruchów i stowarzyszeń katolickich. Kraków: Wydawnictwo Nomos.

Gunnell, J.G. (2017). „Political Concepts and the Concept of the Political”. Teoria Polityki, 1 .

Hirschi, C. (2012). The Origins of Nationalism: An Alternative History from Ancient Rome to Early Modern Germany. Cambridge: Cambridge University Press.

Hoover, K., Donovan, T. (2010). The Elements of Social Scientific Thinking. Boston: Wadsworth Cengage Learning.

Hudzik, J.P. (2011). „Teoria polityki w komentarzach filozoficznych i metodologicznych". W: Z. Blok (red.). Czym jest teoria w politologii? Warszawa: Dom Wydawniczy Elipsa.

Jabłoński, A.W. (2017). „Teoretyczne ujęcia konfliktu politycznego”. Wrocławskie Studia Politologiczne, 22.

Klementewicz, T. (2010). Rozumienie polityki. Zarys metodologii nauki o polityce. Warszawa: Dom Wydawniczy Elipsa.

Kopaliński, W. (1968). Słownik wyrazów obcych i zwrotów obcojęzycznych. Warszawa: Wiedza Powszechna.

Maj, E. (2018). „Egodokumenty w warsztacie badawczym historyka myśli politycznej”. W: S.R. Sielezin (red.). Studia metodologiczne z nauk społecznych. Wrocław: Wydawnictwo IP WNS.

Moses, J.W., Knutsen, T.L. (2007). Ways of Knowing: Competing Methodologies in Social and Political Research. London: Palgrave Macmillan.

Nocoń, J. (2017). „Dyskursywne uprawomocnienie refleksji teoretycznej w naukach o polityce". Teoria Polityki, 1.

Parsons, C. (2007). How to Map Arguments in Political Science. Oxford: Oxford University Press.

Peck, R.S. (1987). We the People: The Constitution in American Life. New York: Harry N. Abrams Inc.

Roget's Thesaurus of Synonyms and Antonyms (1987). Miami, FL: P.S. \& I. Associates Inc. Sadri, A. (1992). Max Weber's Sociology of Intellectuals. Oxford: Oxford University Press.

Scott, J. (2011). Conceptualizing the Social World: Principles of Sociological Analysis. Cambridge: Cambridge University Press.

Sielezin, J.R. (red.). (2018). Studia metodologiczne $z$ nauk społecznych. Wrocław: Wydawnictwo Instytutu Politologii UWr.

Silbergh, D.M. (2001). Doing Dissertations in Politics: A Student Guide. London-New York: Routledge.

Słownik języka polskiego (2008). Warszawa: Wydawnictwo Naukowe PWN.

The Cambridge English Dictionary (1990). London: Grandreams Limited.

Thiele, L.P. (2003). Thinking Politics: Perspectives in Ancient Modern and Postmodern Political Theory. New York: Chatham House Publishers. 
Van Evera, S. (1997). Guide to Methods for Students of Political Science. Ithaca-London: Cornell University Press.

Weber, M. (2002). Gospodarka i społeczeństwo. Zarys socjologii rozumiejącej, przeł. D. Lachowska. Warszawa: Wydawnictwo Naukowe PWN.

Zieliński, M. (2017). Wykładnia prawa. Zasady - reguły - wskazówki. Warszawa: Wolters Kluwer.

Zinn, H. (1999). A People's History of the United States: 1492 - Present. New York: Harper Collins Publisher.

\section{Streszczenie}

Celem niniejszego artykułu jest wprowadzenie do teorii interpretacyjnej, próba zarysowania głównych zagadnień i problemów, jakie nasuwa podejście interpretacyjne w naukach społecznych i politycznych. Do głównych zagadnień analizowanych w artykule należą kolejno: kwestie definicyjne, weberowska tradycja metodologiczna, metoda interpretacyjna w badaniach jakościowych, natura relacji między interpretacją a rozumieniem i wyjaśnianiem, znaczenie podejścia interpretacyjnego w nauce o polityce i teorii polityki. Autor podejmuje próbę ustalenia definicji i etymologii pojęcia „interpretacja”, sytuuje je w rodzinie terminów pokrewnych, rozważa istotny problem naukowego statusu badań interpretacyjnych. Wskazuje także czynniki, które mogą się przyczynić do podniesienia efektywności badań interpretacyjnych w procesach wyjaśniania i zrozumienia działań społecznych i politycznych. W zakończeniu sygnalizuje wyzwania stojące przed nauką, dostrzega w nich pole badawcze dla analizy interpretacyjnej.

Słowa kluczowe: interpretacja, rozumienie, wyjaśnienie, teoria polityki 